\title{
WHO IS AFRAID OF GENDER?: STUDENTS' RESISTANCE TO CRITICAL LANGUAGE TEACHING IN REACTIONARY TIMES
}

\author{
Quem tem medo de gênero?: A resistência discente ao ensino crítico de \\ línguas em tempos reacionários
}

\author{
Leonardo da SILVA \\ Instituto Federal de Santa Catarina \\ leonardo.silva@ifsc.edu.br \\ https://orcid.org/0000-0001-7346-5966
}

\begin{abstract}
This article reports on an action-research conducted by a teacher-researcher with a group of 20 high school students taking the English subject in a federal school in Southern Brazil. Based on the principles of both Task-based language teaching and Critical Pedagogy, critical tasks focusing on gender in the world of work were designed and implemented by the teacher-researcher. Data was collected through students' questionnaires and interviews, and my self-report diaries. The thematic analysis of the data revealed students' resistance to the theme approached in the critical tasks. The study points out that students' opposition to critical reflection seems to be connected to the fact that critical classes deviate from their expectations of what teaching is, since critical teaching moves away from the traditional banking education. A critical understanding of students' contexts (including the macro sociopolitical scenario) is necessary so that rejection may become resistance towards freedom and social justice.
\end{abstract}

KEYWORDS: Critical language teaching; Task-based language teaching; Students' resistance; Social justice.

RESUMO: Este artigo apresenta uma pesquisa-ação conduzida por um professor-pesquisador com um grupo de 20 alunos de Ensino Médio cursando Inglês em uma escola federal no sul do Brasil. Com base nos princípios do Ensino de Línguas Baseado em Tarefas e da Pedagogia Crítica, tarefas críticas com foco em gênero no mundo do trabalho foram desenvolvidas e implementadas pelo professor-pesquisador. Os dados foram coletados por meio de questionários e entrevistas com os alunos, e meus diários reflexivos enquanto professor-pesquisador. A análise temática dos dados revelou resistência dos alunos ao tema abordado nas tarefas críticas. O estudo aponta que a oposição discente à reflexão crítica parece estar conectada ao fato de que aulas críticas não correspondem às expectativas sobre como deve ser o ensino, uma vez que o ensino crítico se distancia do ensino tradicional bancário. Um olhar crítico para o contexto dos alunos (incluindo o cenário sociopolítico macro) é necessário para que a rejeição discente possa se tornar resistência a favor da liberdade e da justiça social. 
PALAVRAS-CHAVE: Ensino crítico de línguas; Ensino de línguas baseado em tarefas; Resistência discente; Justiça social.

\section{INTRODUCTION: CRITICAL LANGUAGE TEACHING IN REACTIONARY TIMES}

As a teacher and a researcher in the field of Language Learning and Teaching, I have encountered several instances of what I would like to call "critical" moments. According to Rocha, Maciel and Morgan (2017), "in a language class, critical moments or moments of 'crises' could occur when the student's or the teacher's interpretive hermeneutic habitus is interrupted by an unexpected point of view" (p. 66). In this sense, I draw on the authors and use the term "critical moments" here to refer to challenging or difficult instances in teaching and learning when a social issue could be approached and discussed from an informed and, therefore, critical perspective in the language classroom. A critical perspective is understood here as a standpoint that questions the ways in which power and oppression operate in society. Being critical implies, thus,

to engage in disruptive, sceptical and 'other' social and discourse relations than those dominant, conventionalised and extant in particular social fields and linguistic markets. To be critical is to call up for scrutiny, whether through embodied action or discourse practice, the rules of exchange within a social field. To do so requires an analytic move to self-position oneself as 'other' even in a market or field that might not necessarily construe or structurally position one as other (that is, on the basis of colour, gender, class etc.). This doubling and 'othering' of the self from dominant text and discourse can be cognate, analytic, expository and hypothetical - or it can, indeed, be already lived and narrated, embodied and experienced (LUKE, 2002, p. 6).

In fact, the need for critical language teaching ${ }^{1}$ is reflected in a number of documents that present the theoretical underpinnings of language teaching. According to the United Nations Educational, Scientific and Cultural Organization (2014):

Education for tolerance should aim at countering influences that lead to fear and exclusion of others, and should help young people develop

\footnotetext{
${ }^{1}$ In this study, I use the term critical language teaching to refer to language teaching practices following Critical Pedagogy principles. It is used, thus, as a synonym of critical language pedagogy. According to Crookes (2013), "critical language pedagogy emerges from the interaction of theories and practices of language teaching that foster language learning, development, and action on part of students, directed towards improving problematic aspects of their lives, as seen from a critical perspective on society" (p. 8).
} 
capacities for independent judgment, critical thinking and ethical reasoning. The diversity of our world's many religions, languages, cultures and ethnicities is not a pretext for conflict, but is a treasure that enriches us all (online).

In this sense, educating for tolerance should be the aim of every discipline. This is even more crucial in language teaching if we understand that language plays a major role in constructing our reality - after all, it is through it that the hegemonic discourses may be challenged or reinforced.

The need for language to be taught from a critical perspective seems even more urgent when one considers the current political and educational situation in Brazil. We have experienced critical moments in the political scenario worldwide and, more specifically, at the national level. By critical moments here I mean important changes that have an important impact on people's lives and human rights in general. With the pervasiveness and the ubiquity of technology, the population has had more access to the media. However, there seems to lack an understanding of the interests that lie behind media messages - especially when one considers that the different media are usually part of big enterprises owned by a few family groups. In addition to that, there has been a rise in the promotion of neoliberalist understandings of education: in Brazil, for instance, we have witnessed cuts in investments in public education and several changes in the high school curriculum (which have been done without the participation of educators, parents, and the students themselves). According to the Brazilian educator and philosopher Dermeval Saviani, the changes that have taken place in terms of educational policies have made us retrocede and is comparable to what education was like in the 40s (GRABOIS, 2017). For Saviani, the so-called high school reform, which divides this level of education in several itineraries, may impose a heavy burden on students at a young age, since they will have to make a choice regarding their field of study from very early on. Furthermore, these changes will most likely once again serve to prevent the working-class from having more intellectual and higher-paying jobs. This is so because the student from an underprivileged background will tend to focus on the itinerary that may provide him/her with the quickest return, that is, the tendency is that the strong focus in high school will be on the professional education itinerary. This is comparable to the 40s when education for the working-class was separate from the education for more privileged students (who 
would later attend universities). For Saviani, this is a project that aims at avoiding the development of critical citizens (GRABOIS, 2017).

Besides, attempts from religious organizations and conservative politicians to prevent organizations from being critical - including public schools - are also commonplace (COWAN, 2014). In 2011, for instance, an educational proposal aiming at promoting awareness and tolerance regarding the LGBT population was presented in the National Congress. Commonly referred to by the mass media as the "gay kit", the project was designed to provide teachers and students with materials that would encourage antidiscrimination actions in the school context. However, it was banned with the argument it would "induce" homosexuality in schools. As the congresswoman Margarida Salomão argued during the debate regarding such project, education itself is ideological, and historically it has been sexist, racist, patriarchal and anti-feminist. In her view, any attempt to deconstruct such hegemonic discourses is therefore legitimate (SALOMÃO, 2015).

Similarly, the new version of the Common Core Curriculum (BRASIL, 2017) - a document that had been initially built in collaboration with educators, parents and students - was edited top-down (that is, without any consultation to the society) and erased different mentions to topics such as "gender identity" and "sexual orientation". This demonstrates that, in the view of these people, the school's role is to transmit scientific knowledge from a neutral perspective, going against the very notion that teaching is inherently political (FREIRE, 1996) ${ }^{2}$. As regards such document, it is also important to mention that it establishes the English language as the mandatory additional language in the school curriculum - there is no longer a need to teach other additional languages, such as Spanish or any other language that is relevant for the specific educational context. Not only does this prevent schools from exercising their autonomy based on their needs, but it also reveals a neoliberalist understanding of education and of the importance of learning an additional language. Marsiglia et al. (2017) claim that the Common Core Curriculum, by emphasizing skills, competencies, procedures and attitudes to be taught at school, presents an educational perspective aiming at preparing students for the work market. It highlights, in this sense, the concept of entrepreneurship and favors students' development according to standardized testing (p. 119). Such analysis corroborates Saviani’s argument

\footnotetext{
${ }^{2}$ For a more detailed analysis of the English Curricular Unit in the Common Core Curriculum from the perspective of Critical Pedagogy, see Farias and Silva (2020).
} 
that such educational policies are actually a retrocess to the extent that they deny the critical (that is, the social, political and ideological) nature of education. Once again, this signals the urgence of developing critical work in the classroom so as to resignify such top-down uncritical policies.

Some politicians have also tried to pass a Law Project misleadingly entitled "School without a [political] Party". According to the project, the educator should only transmit the content of the subject to be taught, as if knowledge itself was neutral. I argue that, in fact, it aims at forbidding teachers to express their views and promote critical thinking ${ }^{3}$. Even though the project has been defined as unconstitutional by the Ministério Público Federal, it is defended by a great number of people who mistake thinking critically for promoting specific and biased political views (DICKMANN, 2017).

But how can one teach critically in such a context in which conservative discourses have gained notoriety? In order to shed some light on this matter, this article aims at analyzing data derived from an action research. This study is of a qualitative interpretive nature (DAVIS, 1995) and its main objective is to understand students' resistance towards critical language teaching from the perspective of both the teacher-researcher - who is also the author of this article - and the students.

\section{CRITICAL LANGUAGE TEACHING IN ACTION: AN ACTION-RESEARCH}

In order to investigate the challenges and possibilities involved in critical language teaching in the context of Basic and Technological education, an action-research took place $^{4}$. An action-research seemed appropriate for such study conducted from the perspective of Critical Pedagogy because it can be "a powerful tool for change and improvement at the local level" (COHEN et al., 2000, p. 226). In fact, this study can also be understood as a participatory action-research, since the teacher is also the researcher,

\footnotetext{
${ }^{3}$ Critical thinking is understood here from the perspective of Critical Pedagogy as "an opportunity and a challenge for students to examine social structure, with its inequalities and systems of power relations" (GIEVE, 1998, p. 124-125). It implies, in this sense, a questioning of one's beliefs or commonsensical views through reflective examination and dialogical debate.

${ }^{4}$ The data presented here derived from a larger study (SILVA, 2018) conducted by the author as part of his Doctoral research. Since the study involved human beings, its project was submitted for appreciation by the Ethics Committee at Universidade Federal de Santa Catarina (UFSC) through the online "Brasil" platform (www.plataformabrasil.saude.gov.br). Given that the study met all the ethical requirements, it was approved by the committee on April $26^{\text {th }}, 2017$ with the number 2.032.334. It was only after the project's approval that data collection took place.
} 
and it utilizes "a qualitative research methodology that fosters collaboration among participants and researchers" (MACDONALD, 2012, p. 46).

Firstly, after conducting a critical needs-analysis (CROOKES, 2013) of my context of investigation - which included a long period of teaching, my subjective knowledge of the context based on my experience with students, their parents and with the school context as a whole, and the administration of profile questionnaires - I designed a cycle of tasks aiming at promoting critical language development among students taking a technical program in Mechanics alongside their high school studies ${ }^{5}$. This is to say that the task unit aimed at promoting students' linguistic development and, at the same time, promoting the development of critical consciousness (FREIRE, 2005) ${ }^{6}$ regarding gender in the area of Mechanics and in the world of work. Comprised of seven tasks (see Chart 1), the cycle aimed at promoting reflection regarding the representation of women in the world of work by the media and at promoting language learning that would foster action that problematizes and avoids gender-bias or stereotypes ${ }^{7}$ :

Chart 1: Cycle of critical tasks

\begin{tabular}{|l|l|}
\hline \multicolumn{1}{|c|}{ Task } & \\
\hline Task 1 & The world of work \\
\hline Task 2 & The world of media \\
\hline Task 3 & Gender in the media \\
\hline Task 4 & Understanding the effect of media in women's lives \\
\hline Task 5 & Fighting against media stereotypes \\
\hline Task 6 & The mechanical technician profession \\
\hline Task 7 & Creating an infographic \\
\hline
\end{tabular}

Source: elaborated by the author.

In this sense, the tasks were conceived from the perspective of both Task-Based Language Teaching (TBLT) and Critical Pedagogy. As Crookes (2013) defines it,

\footnotetext{
${ }^{5}$ In this type of curriculum, high school curricular units are supposed to be taught in connection and in dialogue with the technical curricular units. In the case of English, for instance, the objective is to promote a holistic linguistic educational perspective and, at the same time, to establish links with the world of work (and, more specifically, the area of Mechanics).

${ }^{6}$ Critical consciousness is understood in this study from a Freirean perspective in the context of problemposing education, which encompasses being able to not only critically analyze one's context, but also act upon it.

${ }^{7}$ To see a detailed description of each task and its implementation procedures, see Silva (2018).
} 
Critical pedagogy is teaching for social justice, in ways that support the development of active, engaged citizens who will, as circumstances permit, critically inquire into why the lives of so many human beings, perhaps including their own, are materially, psychologically, socially, and spiritually inadequate - citizens who will be prepared to seek solutions to the problems they define and encounter, and take action accordingly (p. 8).

As Freire (1973) explains, it is not possible to develop critical consciousness in a traditional curriculum, which is "disconnected from life, centered on words emptied of the reality they are meant to represent, lacking in concrete activity (...)" (p. 37). The author criticizes, in this sense, the banking conception of education, in which students are perceived as receivers of knowledge, while the teachers are simply transmitters of it. This implies an educational perspective based on mere memorization and repetition. Since the educational context is also a reflection of power structures, it is not possible for a critical educator to teach coherently (that is, critically) in a type of structure that denies dialogue (FREIRE, 2005). Thus the relevance of devising strategies - in methodological terms - for the development of both linguistic and critical skills.

Task-based language teaching is defined as

an educational framework for the theory and practice of teaching second or foreign languages. Based on empirical research, TBLT adopts meaning-based, communicative tasks as the central unit for defining language learning needs, determining curriculum goals, designing activity in the (language) classroom, and assessing language competencies (TBLT, 2018).

Task-based language teaching was perceived as adequate for approaching language from a critical perspective not only because it provides a methodological framework for how to design and implement meaning-focused and goal-oriented activities, but also because its philosophical underpinnings seem to be aligned with a critical perspective. According to Long (2015), we should move beyond the cognitive rationale behind TaskBased Language Teaching and recuperate its philosophical principles of "learning by doing" based on authors such as Dewey (1950) and Freire (1996). Such principles would include individual freedom, rationality, emancipation, learner-centeredness, egalitarian teacher-student relationship, participatory democracy, and mutual aid cooperation. For Ellis (2003), a critical understanding of task-based language teaching is important because 
it "forces us to go beyond the psycholinguistic rationale [...] to examine the social, cultural, political, and historical factors that contextualize teaching and how it takes place" (p. 333).

In order to investigate the process of implementing the critical cycle of tasks, the 20 students - whose age ranged from 16 to 18 years old and were all pursuing a technical degree in Mechanics alongside their high school studies - answered questionnaires at the end of each class and also participated in oral interviews with the teacher-researcher. The implementation and data collection took place over of the period of two and half months through weekly meetings of 1 hour and 50 minutes. Both the questionnaires and the interviews aimed at identifying students' perceptions regarding the implementation of the critical tasks. I also kept self-report diaries in which, after each class, I wrote about my impressions on the implementation of the critical tasks ${ }^{8}$.

The data derived from the tabulation of students' questionnaires and the transcription of recorded interviews as well as from my self-report diaries were analyzed through a thematic analysis. As Yukhymenko et al. (2014) state, "thematic analysis is the search for and extraction of general patterns found in the data through multiple readings of the data" (p. 96). Then, such themes, identified by the researcher and a rater (to ensure reliability), became the categories for data analysis. In this study, I focus on one specific theme that emerged in data analysis: resistance. Resistance is defined here as an action or a discourse that shows discontent with the focus/topic of the class. Firstly, I shall analyze and discuss the data from the students' questionnaires and interviews and then focus on the teacher-researcher's self-report diaries.

\section{DATA ANALYSIS AND DISCUSSION}

\section{Students' questionnaires}

The questionnaires were applied at the end of each class and they contained open questions in which the students were asked what they had learned from the class, whether they had experienced any difficulties, what they thought of the theme of the class and whether they had other comments or suggestions. Even though most students described

\footnotetext{
${ }^{8}$ The questionnaires and interviews were all in Portuguese, while the diary notes made use of both English and Portuguese. In this article, all the data excerpts are translated into English.
} 
linguistic and critical aspects that they had learned in the classes, there were some students who mentioned that the topic covered (that is, gender in the context of Mechanics and in the world of work) was irrelevant. More precisely, a couple of students described the theme of the classes as not relevant in the first classes of task implementation. These students mentioned that the classes showed only one perspective and commented that it should be impartial or that it had "no content". Such views, which were taken into consideration by meduring task implementation, influenced the adoption of certain strategies for my mediation (for more on this, see SILVA, 2020). This initial resistance to the topic of the class seems to have changed throughout task implementation, since by the end of it some students actually emphasized that the classes presented different points of view or allowed them to get to know perspectives that were different from their own.

In the responses regarding the section for additional comments or suggestions, instances of discontent regarding the critical theme of the classes or the way critical discussion was approached could be identified. This was observed specifically in the questionnaires for classes 1 and 2:

Table 1: Students' answers to the question "Do you have any other comment or suggestion about today's class?" in Classes 1 and 2 -translated from Portuguese

"I didn't like it. It's relevant, but I think it was badly applied in class. I think the class should be more impartial regarding the topics that are presented, since the teacher insists on approaching these topics" (Cristian").

"Don't approach controversial issues (politics, sexuality, inequality, etc) if you don't open for discussion. We as students feel that you are trying to push an 'ideology' (an opinion or something like that) into the students" (Cristian).

"Maybe it would be good to get a better speaker and also to be more impartial regarding the choice of videos, showing the theme in general and not only a "social cause' in it" (Robson).

"The teacher should not give moral lessons and impose his ideology" (Ray).

"More impartiality, please" (Alisson).

The students' answers indicate that, from their perspective, classes should not approach social themes or at least should be "impartial" and neutral. This can be explained based on the students' experiences with a more traditional type of education, which considers knowledge as neutral. They seem to believe, in this sense, that certain topics

\footnotetext{
${ }^{9}$ Pseudonyms are used in order to ensure that students' identities remain anonymous.
} 
should not pertain to the school sphere - which could also be associated to the fact that it might be uncomfortable for them to approach them, since they will probably encounter views that are different from their own and that contradict their ways of living (HOOKS, 1994). Moreover, they also seem to have felt that there was not actually discussion in the classroom, since they mention "imposition" by the teacher. While this discourse on "imposition" can also be seen as a result of the broader political and social context in which they were inserted (as we shall see in the analysis of the teacher-researcher's selfreport diaries), the students' answers also made me reflect upon strategies on how to approach a critical theme and promote the development of critical consciousness through dialogue. Except for one comment in the questionnaire for class 10 (in which a student states that there should be more space for "opening up discussions" about the topics approached in class), this resistance regarding the critical theme of the class was no longer presented in their answers after class 2 . However, as we shall see, such resistance appears in other moments, such as in the interviews. hooks (1994) explains, in this sense, that changing paradigms in terms of the teaching and learning process is not immediately accepted by students, since "it takes time for students to experience that challenge as positive" (p. 42).

\section{Semi-structured interviews}

The semi-structured interviews took place during the period of taskimplementation since the focus was on the students' perspective regarding the teaching and learning process (rather than on a final product only). Before the beginning of each interview, I presented the participant with the tasks that had been implemented up to that moment and reminded him/her that the questions should be answered taking into consideration these specific classes. However, as we shall see, at times participants make references to classes other than the ones pertaining to the implemented tasks (or even to classes from previous semesters).

During the interview, the participants were asked about how they felt about the classes up to that moment, what they thought they had learned, what they thought about the topic/theme of the classes, whether they believed the classes had contributed to their education in the technical high school program, whether they had experienced any type of 
difficulty, and whether they had any other comment, suggestion or criticism regarding the classes. Since these questions were part of semi-structured interviews, other questions were added depending on the students' contributions. Besides, I also made sure the students fully understood the questions by paraphrasing them when necessary.

Besides reporting on linguistic and critical aspects that were learned, students also engaged with me in critical moments during the interview. These were instances in which critical reflection regarding the classes was instigated by me or by the student. Most of these moments took place after a student presented some type of criticism either to a topic approached in class or to the way it was approached.

One example of a critical moment took place when a student was asked whether he had further comments or suggestions regarding the classes. He commented on one activity from the previous semester in which the students read a news report discussing Donald Trump's decision to build a wall to prevent immigrants from entering the United States. According to this student, the activity did not allow for the students to express their views, since he felt that they had to agree on the negative aspects of the construction of the wall:

\begin{abstract}
the teacher, for example, gave us a news report about Trump's wall, then in the activity you asked us to describe the negative aspects of Trump's wall. Of course there are negative aspects, but in my opinion, in my idea, just like in my friends' too, there are constructive aspects, good aspects... Since the question asked us to number the negative things, we had the impression that the entire class was against him, but many people are in favor. So we could not express ourselves in relation to that activity. For example, it is bad that many family members cannot visit people there... What will people's minds be like when they cannot see their people, they will miss them and everything, the emotional part, right? But I would rather not see a family member of mine than see my entire nation dying. Because there is a lot of influence of terrorism. It's my opinion, of course, and I respect the teacher's too... (Michel, translated from Portuguese).
\end{abstract}

Another student also commented on the same activity:

I am going to be sincere with the teacher, I even included this in the first questionnaire, I think I even expressed it in a bad way, I might have been rude, so I apologize for the teacher... I am going to use as an example what you said once about Trump, you talked about immigration, and you said bad things about Trump. I don't agree with Trump, with almost anything [he says], but this is a controversial topic and the teacher approached one side of it, and it would be interesting to approach both 
sides of controversial issues, even when you don't agree with it. This is best for the class, otherwise we end up creating an influence on opinions and this may frustrate some students. But it was nothing serious. Just leave the discussions open in these subjects... (Cristian, translated from Portuguese).

In spite of the fact that in the excerpts above the students reflect on an activity that was not part of the critical tasks (they had had classes with me for the entire period of the semester prior do data collection itself), they raise important aspects of their perspectives on the classes in general. The fact that they still remember this activity - implemented several months prior to critical tasks implementation - suggests that the activity had an impact on them. Both students felt like the activity did not allow students to express their different views and, therefore, expressed some resistance to it. Even though the reading activity was part of a series of activities with the theme of immigration, it seems that, at least for these students, critical reflection through dialogue did not really take place. This points out to the necessity of first understanding students' views in order to present them with the opportunity to juxtapose them with other ways of viewing the world that may promote social justice (HOOKS, 1994). In other words, it seems that the activity did not allow the students to engage in their own reflexive process, since the arguments were "already-made" for them. Students expressed resistance possibly due to the fact that they were not capable of building an argument based on evidence, but were rather presented with one to be either "accepted" or "rejected".

Furthermore, in both interviews I tried to explain to the students that the text about Trump's wall presented a point of view and, just like any other text, was not neutral. He also argued that this should not prevent them from expressing their own views and from questioning the "truths" contained in each text, but this should be done with arguments and evidence. The interview served, in this sense, as a moment for me to elaborate on the issue of immigration, promoting reflection regarding unresolved issues and, ultimately, to bring students and the teacher-researcher closer:

This topic of immigration can be connected to something we learned in the first semester when we worked with magazine covers that represented Africa. And we worked with a magazine cover that showed the image the media constructs of terrorists. So it's nice to think of why we have this image. Who are the bad people [in this image]? They are the people who come from another country... And we generalize, right? 
We think that everybody... And we need to be careful with this association of immigrants with terrorism... We cannot generalize. One question we can make is: stopping people - which is a human right that everybody should have - from coming and going... If I want to go to another country I have this right, of course there are laws, some countries require a visa, but people have this freedom. As we have seen, in the history of humanity people have migrated. People were not born in one place and stayed there forever. Otherwise we would not have people all over the world. So if we think about this, and we reflect about the wall, we have more tools to understand it. So who can decide where people can go? Does a wall end with the problems? I don't know, these are questions that I am making for us to think. It is in this sense that I think we need to reflect. My objective when we discussed immigration was the following: is immigration bad? How do we welcome those who come from other countries? We have immigrants here, for example. And to show how immigration is a part of life. My family has immigrants. And this was present in your presentations, in the people you interviewed. So we need to be careful not to reproduce this idea created by the media that the immigrant is a bad person, a terrorist. Terrorists are specific people, of course we need to think of actions to prevent [terrorism], since it kills people and everything, but what is the best way? I don't know, I don't have the answer either. It's difficult to work with this topic. (Teacher-researcher, translated from Portuguese).

While such critical moments can be seen as positive to the extent that they allowed me to get to know students' perspectives and also promote further critical reflection, they also indicate the importance of conceiving tasks that may engage students in analyzing their own assumptions by accessing different evidence regarding a topic. The connections I made between media representation and the stereotype of the immigration were probably not part of the students' understanding of immigration. Thus, when presented with a view that diverged from their established "myths" (FREIRE, 2005), students resisted. The resistance from some students to the topics approached in class can be seen, in this sense, as originating prior to the present study.

I also asked one of the students whether he also had the impression that there was not space for "open discussion" in the critical tasks and he stated that he felt that different opinions were being heard in the classroom in the more recent activities. On the other hand, another student stated that the fact that the classes considered different opinions was negative since it may give rise to conflict:

The student gives an opinion and it's okay, maybe it's not right, but sometimes [someone] disagrees, and this person may even be right, then someone else disagrees and we have a discussion about a certain topic. 
And then we are studying another subject, someone says something, and someone else gives their opinion... And then a third person gives another opinion and this creates a conflict, and I believe this disturbs the class. (Alisson, translated from Portuguese).

For this student, listening to people's opinions distracts from the aims of the class. Thus, it seems that in his view knowledge is neutral and learning cannot occur from critical reflection promoted through dialogue. First, this indicates that students might still be learning how to engage in critical discussion and critical reflection. Second, it demonstrates the importance of developing the students' awareness regarding the teaching and learning process - that is, they need to understand why dialogue is an important part of the class. It is with this last intent in mind that I tried to explain for this student the importance of listening to other people's views in the class:

Don't you think that people can, based on discussion... Like, I have never thought the way that person thinks, and that person has never thought the way I think... So there needs to be a dialogue. It can't just be like "I think this, you think that, and that's okay", because this way there is no reflection. But if a person has an opinion and I can understand that opinion, and I need to have arguments too, to understand it that makes sense or not and why. So if it's just a matter of "I think this, you think that" and we get angry at each other... (...) Then there is no purpose, but if it's a process of construction, of reflection...(Teacher-researcher, translated from Portuguese).

One last critical moment took place when a student stated having learned about the difference in salaries for men and women with sports careers:

In our last class we had the example that showed the salary of people in sports, which is what I recall now... I never imagined they would make so little money, I mean... women would make so little money. I still believe that it's because they don't participate a lot in these sports, and that these sports emerged in a male context, but it's still very little [money]. They are not valued (Cristian, translated from Portuguese).

The student in the previous excerpt recognizes gender inequality while comparing men's and women's salaries in sports, but he still sees this as a consequence of the lack of individual participation. In this sense, he seems to be in the process of developing his critical understanding of gender inequality. Because of that, I used this opportunity to promote a deeper reflection, explaining that the "lack of participation" of women in sports 
was not a mere individual decision, but actually a result of an unequal social structure in which girls are not associated with sports:

So we need to think what people associate sports with, right? Like, who is more encouraged to play sports? Who is more encouraged or motivated and who receives more incentive? So it's actually a cycle, right? You see fewer people... fewer women playing soccer, for example, so girls think they should not play soccer, they don't play it, they think it's not an activity for them... so it's a cycle, right? It's structural, we call it structural, something that is created by society. (Teacher-researcher, translated from Portuguese).

The student seems to have understood the teacher's argument, since he agreed by saying: "So women are born in a context where there is a lack of female participation [in sports] so..." (Cristian, translated from Portuguese). It is possible to observe, thus, that due to the complexity of critical development, it is necessary to provide different opportunities for examining one's views regarding a specific topic. Even though this student had already completed a series of tasks that aimed at fostering critical reflection regarding gender inequality, he had the opportunity to move one step further while considering the wider context of "structural inequality" mentioned by me.

In this sense, the semi-structured interviews seem to have extrapolated their role as an instrument for data collection - by allowing students to express their views in a safe environment, I could get to know their impressions better so as to try to engage them in critical reflection. This can be seen as very productive, specially when one considers that during the interview the students do not feel the peer pressure they might feel in class.

\section{Teacher-researcher's self-report diaries}

In order to better understand students' resistance towards critical language teaching in this study, it is also relevant to analyze the teacher-researcher's self-report diaries, in which I reflect on the implementation of critical tasks. At the same time that my reflections on the classes point out moments that promoted a positive attitude from the students, they also discuss resistance from them. In this sense, I argue in my notes that the school is traditionally thought as a very normative space. Such norms would include the division of disciplines, the roles of teachers and students, the arrangement of chairs in a 
classroom, among other aspects. In this sense, creating a rupture from a transmissionbased system (FREIRE, 2005) and, even further, bringing a critical perspective to school, is very challenging. hooks (1994) discusses such challenge by reflecting on her experience as a critical teacher:

Teaching in a traditional discipline from the perspective of critical pedagogy means that I often encounter students who make complaints like, 'I thought this was supposed to be an English class, why are we talking so much about feminism?" (Or, they might add, race or class.) In the transformed classroom there is often a much greater need to explain philosophy, strategy, intent than in the "norm" setting. I have found through the years that many of my students who bitch endlessly while they are taking my classes contact me at a later date to talk about how much that experience meant to them, how much they learned (p. 42).

Thus, not only should a teacher be aware of the fact that the students have their own perceptions or expectations of what an English class is like (because they are used to the school "norms" that dictate that), but s/he should also bear in mind that critical development happens through time and that resistance might be an initial and important step of such process. At the same time, the data analysis seems to indicate the importance of explaining for the students the reasons why classes are structured in a certain way (as we have seen, some interviews with the students contained moments in which they could better understand - or at least discuss about - the teacher-researcher's intentions). As hooks (1994) states, "to educate for freedom, then, we have to challenge and change the way everyone thinks about pedagogical process. This is especially true for students. Before we try to engage them in a dialectical discussion of ideas that is mutual, we have to teach about process" (p. 144). Moreover, because the students do not seem to be used to learner-centered teaching and learning, they need to receive guidance on how to perform their role as subjects of their own learning process. In this sense, the role of students needs to be resignified. In my notes I write, for instance, that the students seem to be too much concerned about completing activities in order to receive grades and be approved, which might hamper their ability to actually engage in the process of critical development.

I also made reference in my self-report diaries to contextual issues that might have influenced my practice. The analysis of such contextual moments is important since in order to understand any educational context from a critical perspective, it is necessary to 
go beyond what happens in the actual classroom. This is so because the classroom is not disconnected or immune from the wider educational, social, political and economic contexts. Perhaps one of the challenges of critical language teaching is being able to promote critical consciousness in a context where doing so is "going against the grain".

The first "contextual comments" refer to events observed by me that took place in the context of the institute in which this study was carried out. During task implementation, the school organized an event to celebrate the library week with the theme "gender issues". The event consisted of different activities in the library aiming at fostering students' reflection regarding gender inequality: there were lectures, roundtables, movie screenings, posters featuring books on gender, among other activities. I invited some of his students to create posters with sentences that would instigate reflection regarding gender relations, for instance. The students came up with the idea of including posters in the restroom mirrors about gender inequality so that everyone would notice them. One of the posters said, for example, that "a woman's place is where she wants to be". On the same day the posters were displayed, the participants of the study noticed that some had disappeared while others had been written on. In this specific poster, for instance, someone (in the men's restroom) wrote that "a woman's place is thus at the toilet (seat)". Similarly, on the campus page on Facebook, people - including parents - left comments questioning the relevance of discussing gender during library week. From these facts alone we can observe a resistance regarding approaching the theme of gender that is not exclusive to the class or the students that took part in this study.

In addition to that, a councilman from the city where the school is located proposed - at the time of task implementation - a law project that had the objective of prohibiting the so-called "gender ideology" at school ${ }^{10}$. As Reis and Eggert (2017) explain, the idea of "gender ideology" is actually a fallacy that has been reproduced by conservative sectors of society that fail at understanding that promoting gender and sexual equality is indeed necessary to overcome educational inequalities. Among the arguments from those who defend such uncritical view is that discussing gender at school is an

\footnotetext{
${ }^{10}$ It is interesting to notice that the city council, which is where the discussions regarding such project took place, is located next to the school campus. This physical proximity also demonstrates how this wider context was not distant (literally and metaphorically) from what took place in the classroom. Fortunately, the project was later rejected by the city council, but there were cities in other parts of the country that actually implemented it.
} 
attempt to end with the idea of the traditional family, to promote pedophilia and to "induce" homosexuality. In this sense, the lack of knowledge regarding what gender actually is as well as regarding its conceptual importance for the understanding of social relations seems to have created a panic crisis, in which people who defend or study gender were demonized (p. 20). I believe this is potentialized by several traditional religious beliefs and by the lack of critical media literacy at a time characterized by the ubiquity of unreliable information ${ }^{11}$.

On top of the project proposed by the councilman trying to prohibit gender discussions at school, the school was contacted by the Guardianship Council ${ }^{12}$ due to a denouncement made by a parent who argued that the content of the library week events was not appropriate for teenagers. In my self-report diaries, I report that, as part of the organizing committee, I had to help the other organizers answer the organization in a document explaining the content of each activity and justifying them based on the law (such as the principles of Human Rights and in the Constitution itself) and on the school's mission.

As Seffner (2017) explains, the school is part of the public sphere (unlike the home) - and it is its role to provide the students with different perspectives:

The public space is not an extension of the private household environment, and it is unthinkable that it would be governed by a domestic logic. In the home environment, we can choose who to associate with and set out our own ways of proceeding, within the limits of the law, of course. In the public space, we come across individuals who are different from us, and we from them, in many attributes. This is an important mark of life in society. In Brazil, we are accustomed to saying that the family is the base of society. On the contrary, the base of society is the public space, a place of negotiation and respect for diversity, where we learn to live with differences by perceiving that our political opinions and preferences may be very different from those of others (p. 4).

From this perspective, when a parent believes diversity should not be part of the curriculum, s/he is in fact relying on the idea that education is about transmitting "neutral"

\footnotetext{
${ }^{11}$ The term "fake news" has even become part of several dictionaries in the last few years referring to false information that is disseminated as if it belonged to actual news reporting. Such pieces of news are constantly shared among people through social media.

${ }^{12}$ The Guardianship Council ("Conselho Tutelar", in Portuguese) oversees the rights of children and teenagers.
} 
and "objective" facts. Just like the students, parents' beliefs are also an important factor that may influence the teaching-learning process. What this suggests, in this sense, is that a critical project for teaching cannot be the endeavor of only one teacher. Moreover, it should also involve parents (especially when it comes to basic education), since they should also understand the pedagogical practices that their children are engaging in.

All of these events seem to have affected me - as the teacher-researcher - on a personal level, since I even wrote in my diary that I felt threatened as a professional and as an individual. In this sense, even though I was aware that my pedagogical practices were morally and ethically grounded (and followed national educational documents), the fact that conservative sectors were given voice in society made me feel as a target. As Pennycook (2009) says, "critical work is dangerous work" (p. 138), in the sense that it defies the already-established forces in society.

According to the self-report diaries, such feeling of threat seems to have been intensified by many other examples of schools which had projects on gender and sexuality censored because of the pressure of conservative religious and political groups. There was even a law project at the national level proposing that Paulo Freire should no longer be considered the "patron" of Brazilian education. After witnessing all these events, I decided not to exhibit a documentary on gender equality as an extracurricular activity. Even though I continued promoting discussion on gender in the classroom, I felt like I had to do so with caution.

In one of the classes during task implementation, a student decided to ask me what I thought about one of the activities from the library week. This activity was a lecture by a university professor specialized in Gender studies, and the student thought it was strange that a renowned school such as the institute would invite a professor who was being sued to give a lecture. Interestingly enough, such professor was being sued exactly because of and by such conservative voices who demonize gender studies. What could be noticed from the student's view was that she did not like the lecture but she could not justify why. In this sense, it seems that the students, surrounded by such anti-gender discourses, also felt threatened. In this sense, the strategy of some students was to stand against such activities. Besides, it is my belief that the format of a lecture does not seem to work so as to allow students to rethink their own conceptions, since it is a transmission-based perspective. It seems that the critical tasks allowed them to bring their own perspectives 
and to work with gender issues in simple terms. In this sense, unlike in a lecture, there was dialogue that promoted critical thinking.

As we have seen in the introduction, the federal government actually excluded the terms "gender" and "sexuality" from the document that establishes the national common core curriculum for regular schools. The Institute where the study was carried out, on the other hand, released a document acknowledging the importance of promoting education for social justice that is, therefore, based on Human Rights' principles. In this sense, as Seffner (2017) argues, "education is a task that has obvious political implications and the dispute over the acceptance or not of gender and sexuality issues on the curriculum reflects this exactly" (p. 4). Thus, the context in which the study was carried out is a polarized one, in which hegemonic discourses have gained strength and power, promoting alienation and reinforcing certain myths (FREIRE, 2005). This is, once again, an evidence for the need of Critical Pedagogy in this context.

\section{FINAL CONSIDERATIONS}

The analysis of students' perceptions through questionnaires and interviews and of my self-report diaries suggests that, even though the topic of gender in the world of work was at first received with resistance - which needs to be understood based on the political and educational scenario in the country -, the students' attitudes seem to have changed throughout the implementation of the tasks. The resistance that was observed mainly in the initial tasks was not observed later on, possibly because I, as the teacher-researcher, had to reconsider my teaching practice based on their feedback. In this sense, by understanding students' views I could devise strategies to create moments that would allow students to engage in the process of critical consciousness development (FREIRE, 2005 ) - in other words, they had to think for themselves while completing tasks (with the teacher's and their peers' mediation) instead of having "truths" imposed on them on a topdown fashion. I argue, thus, for the importance of the use of statistics or data, allowing them to develop more elaborate and consistent arguments based on facts and evidence. At the same time, the analysis suggests that critical development is not linear and, thus, should be a continuous process that cannot be reduced or limited to one critical set of tasks. 
Actually, the instruments used for data collection seem to have extrapolated their role, since they also served as moments for the students and the teacher-researcher to deepen their reflection regarding topics approached in class, as well as to reflect about the learning process itself and develop metacognitive awareness. This highlights the importance of devoting moments for students' (self)reflection - even if in their mother tongue - during the teaching-learning process.

Data also pointed out the importance of acknowledging the participants' subjectivities (HOOKS, 1994) in the teaching-learning process. That is to say that, in order to actually promote the development of critical consciousness, I had to not only examine my points of view but also get to know the students' to avoid falling back into transmission-based education (and imposition). Even though I intended from the very beginning to create a democratic atmosphere in the classroom, this was not perceived as so by some students. That was possibly due to the fact that they did not share the assumptions I had regarding gender and other social issues. Consequently, when I simply presented my "ready-made" arguments, they disapproved them since they were not in accordance with their world view. It was necessary, thus, to create conditions for them to develop their own arguments after being exposed to perspectives that were different from theirs - which was done not only through tasks but also through the promotion of dialogue. In this sense, it was mainly through critical dialogue that the participants of the study could exercise their agency and consequently, revisit their beliefs, juxtaposing them with other points of view, data, and logical arguments. As hooks (1994) explains, for critical development to take place, it is necessary to recognize the students' subjectivities, to promote non-hierarchical classroom relations and to encourage critical dialogue.

At the same time, the analysis highlights the influence that the macro sociopolitical context of public policy, law making and commonsensical discourses has on creating resistance towards critical language teaching. Based on that, we can say that for critical work to be truly effective, it needs to go beyond the classroom and involve not only teachers and students, but also families, policy makers and society in general. If the aim of critical language teaching is to seek social justice, it should be a fight of all those interested in creating a more equal society. Perhaps besides questioning "Who is afraid of Gender?", we should also try to understand why people might fear it - that is, to me, the starting point of any true critical dialogue towards the promotion of critical language 
development in and outside the classroom.

\section{REFERENCES}

BRASIL. Base Nacional Comum Curricular. Brasília/DF: MEC/SEF, 2017.

COHEN, L., MANION, L.; MORRISON, K. Research methods in education (5th ed.). London: Routledge Falmer, 2000.

COWAN, B. A. "Nosso terreno". Crise moral, política evangélica e a formação da "nova direita' brasileira. Varia História, 30(52), 2014, p. 101-125.

CROOKES, G. V. Critical ELT in action: Foundations, promises, praxis. New York: Routledge, 2013.

DAVIS, K. A. Qualitative theory and methods in applied linguistics research. TESOL Quarterly, 29(3), 1994, p. 427-453.

DEWEY, J. Democracy and education. New York: Macmillan, 1950.

DICKMANN, I. Paulo Freire Vive! 20 anos de memória e presença na práxis dos educadores. In: DICKMANN, I. et al. (Orgs.), Pedagogia da Memória. Chapecó, SC: Sinproeste, 2017, p. 33-40.

ELLIS, R. Task-based language learning and teaching. Oxford: Oxford University Press, 2003.

FARIAS, P. F.; SILVA, L. I'm gonna leave you with the backlash blues: uma análise acerca da concepção do ensino de língua inglesa na base nacional comum curricular sob o viés da pedagogia crítica. Revista e-Curriculum, [S.1.], v. 18, n. 1, p. 137-157, mar. 2020. DOI: <https://doi.org/10.23925/1809-3876.2020v18i1p137-157>.

FREIRE, P. Education for critical consciousness. New York: Continuum, 1973.

FREIRE, P. Pedagogia da autonomia. São Paulo: Paz e Terra, 1996.

FREIRE, P. Pedagogy of the oppressed. New York: Continuum, 2005.

GIEVE, S. A reader reacts... TESOL Quarterly, 32(1), 1998, p. 123-129.

GRABOIS. Demerval Saviani afirma que o golpe retrocedeu a educação para 1940, 2017. Retrieved from: <http://www.grabois.org.br/portal/entrevistas/154063/2017-1215/dermeval-saviani-afirma-que-golpe-retrocedeu-a-educacao-para-1940 $>$ Access on July 24th, 2020. 
HOOKS, B. Teaching to transgress: Education as the practice of freedom. New York: Routledge, 1994.

LONG, M. H. Second language acquisition and task-based language teaching. Oxford: Wiley-Blackwell, 2015.

LUKE, A. Two takes on the critical. In: NORTON, B.; TOOHEY, K. (Eds.), Critical pedagogies and language learning. Cambridge: Cambridge University Press, 2002, p. 2129.

MACDONALD, B. Understanding participatory action research: A qualitative research methodology option. Canadian Journal of Action Research, 13(2), 2012, p. 34-50.

MARSIGLIA, A. C. G. et al. A base nacional comum curricular: um novo espaço de esvaziamento da escola no Brasil. Germinal: Marxismo e Educação em Debate, 9(1), 2017, p. 107-121. DOI: <http://dx.doi.org/10.9771/gmed.v9i1.21835>.

PENNYCOOK, A. Critical applied linguistics: A critical introduction. Mahwah: Taylor \& Francis, 2009.

REIS, T.; EGGERT, E. Ideologia de gênero: Uma falácia construída sobre os planos de educação brasileiros. Educação \& Sociedade, 38(138), 2017, p. 9-26.

ROCHA, C. H.; MACIEL, R. F.; MORGAN, B. Critical perspectives in language education and literacies: Discussing key concepts. Revista de Letras Norte@mentos,10(23),2017,p.64-80.

SALOMÃO, M. Margarida Salomão discursa sobre ideologia de gênero na Comissão de Educação, 2015 [YouTube Channel]. Retrieved from: $<$ https://www.youtube.com/watch?v=um6DDczsycE $>$. Access on July 24th, 2020.

SEFFNER, F. They want to know everything but are told nothing: is an education without gender and without sexuality desirable? In Proceedings from $13^{\circ}$ Mundos de Mulheres \& Fazendo Gênero 11. Florianópolis: Universidade Federal de Santa Catarina, 2017.

SILVA, L. Critical tasks in action: the role of the teacher in the implementation of tasks designed from a critical perspective. Ilha do Desterro A Journal of English Language, Literatures in English and Cultural Studies, [S.1.], v. 73, n. 1, p. 109-128, jan.2020. DOI: <https://doi.org/10.5007/2175-8026.2020v73n1p109>.

SILVA, L. Teaching English for Critical Language Development: investigating the implementation of a critical cycle of tasks in the context of basic and technological education. (Unpublished Dissertation). Universidade Federal de Santa Catarina, Florianópolis, Brazil, 2018.

TASK-based Language Teaching, 2018. Retrieved from: <www.tblt.org $>$. Access on July 24th, 2020. 
UNESCO. Promoting tolerance, 2014. Retrieved from: $<$ http://www.unesco.org/new/en/social-and-human-sciences/themes/fight-againstdiscrimination/promoting-tolerance/>. Access on July 24th, 2020.

YUKHYMENKO, M. A.; BROWN, S. W.; LAWLESS, K. A.; BRODOWINSKA, K.; MULLIN, G. Thematic analysis of teacher instructional practices and student responses in middle school classrooms with problem-based learning environment. Global Education Review, 1(3), 2014, p. 93-109.

Recebido em: 03 ago. 2020.

Aceito em: 21 out. 2020. 